\title{
The Role of Electronic Customer Relationship Management in Tourism Sector: A Case Study of the Egyptian Travel Agencies
}

\author{
Marwa Fawzi Abdel Warith \\ Tourism and Hotels Faculty \\ Sadat City University
}

\begin{abstract}
It is commonly accepted nowadays that knowing the customers is important for running successful e-business in tourism. Electronic Customer Relationship Management (e-CRM) is a relatively new approach for travel agencies to manage and understand their customers in order to provide better quality products and services. The purpose of this study is to highlight the important role of Electronic Customer Relationship Management for tourism sector in Egypt from the Egyptian travel agencies' viewpoint. A survey approach was implemented to collect data from 350 respondents from travel agencies using a completed questionnaire technique. The outcomes of the present study show that travel agencies in Egypt still need more efforts to achieve successful CRM, through the implementation of applications. The study also describes the e-CRM models of interaction between tourism companies and their customers at both local and global levels. It concludes that the e-CRM should be looked at as a basis for a company's competitive advantage and marketing, because it enables organizations to understand and capitalize on the knowledge they have about their customers with the aim of maximizing profitability.
\end{abstract}

Keywords: Electronic Customer Relation Management (e-CRM), Egypt, travel agency, tourism, site

\section{Introduction}

In 1988, the World Tourism Organization decided that comprehensive, personalized, and up-to-date information is the successful key to recognize customer needs and to acquire potential clients (Buhalis, 1998). Customer Relationship Management (CRM) application is an approach to achieve these successful keys. In the era of e-business and e-commerce, tourism industry faces many challenges, such as the competitive advantage and its management that supports customers and suppliers. The internet supports and helps e-CRM keep their customer build, keep and maintain their loyalty. Customer relationship management helps companies recognize customer needs and manage these relationships efficiently, in order to achieve loyalty and retention. Such approach keeps customer's loyalty and retention and supports the company to gain market share with reduction in operational costs and competitive differentiation (Ghavamr, Olyaer, 2006). There is no doubt that, the Internet is considered as the most important distribution channel and effective tool of tourism information and sale. The Internet is a primary tool of business to e-business. Through the Internet suppliers pass their products to intermediaries in the value chain and thus maximize their profit. Therefore, tourism companies should enhance their e-business to manage their relationships with intermediaries and users (Pulevska, 2008). Moreover, the Internet supports tourism suppliers, as it explores transparency, speed, convenience, and flexibility with market share (Buhalis, 2011). Therefore, the e-CRM plays an important role as an application of e-business through the internet for the tourism sector and for tourism enterprises. It creates strong relationship between providers and their customers. The Internet and the web technologies have highlighted new competition for airlines service and travel agencies. Through its benefits, interactivity, speed, ease, and reduction of cost the Internet technologies try to meet customer satisfaction and customer acquisition (Cheng and Ab Hamid, 2011). Furthermore, the Internet technologies can operate as a new marketing and distributing channel for the tourism companies which know their customer well by establishing CRM system through e-commerce. The latter could be the direct and effective communication channel with customers (Constantelou, 2002). In addition, the Internet is the platform and base for this communication and e-CRM is the expansion of CRM (Alford, 2001). On the other hand, the Internet provides consumers with fast, easy, and cost-effective ways of contacting the providers of travel and tourism-related products and services.

In fact, the travel and tourism industry use the Internet to distribute their tourism product and services to customers through direct, and interactive, tools at a lower price. In the meantime, it offers suppliers and e- intermediaries the value-chain and, thus, maximizes their profit and revenue. Travel agencies should apply and develop the new trends to improve their relationship with intermediaries and customers. As a result, e-CRM provides travel and tourism companies with the opportunity to gain customer loyalty (Constantelou, 2002). Furthermore, customer relationship management $(\mathrm{CRM})$ will become the natural innovation for (e-CRM) in the travel and tourism industry. Besides, the widespread use of the Internet and Technology systems (Greenberg, 2002), CRM develops into electronic costumer relation management that includes elements such as email, chat rooms, interactive websites, social media and e-forums (Lee-Kelley et al., 2003). Tourists' purchasing motivations have been encouraged and developed by the innovation and the wide spread of the Internet business, models, product transparency, and online price. Hence, costumer will be more 
aware of price, less brand loyal, more mature and more experience (Gilmore \& Pine, 1997; Sigala, 2005b; Christou, 2003).Valuable e-CRM is becoming essential. Moreover, the Internet with ICTs application provides sides of strengths for innovation in customer relations management. These new applications may support customer choice and encourage their desire to make a decision (Constantelou, 2002). Indeed, e-CRM highlight the opportunities to gain customer satisfaction, online sales, website patronage, loyalty and retention (Feinberg and Kadam, 2002; Kotorov, 2002; Anton and Hoeck, 2002).

In addition, CRM is a new approach and one of the most important concepts for managing and marketing tourism. To some extent, CRM uses the implementation of Web 2.0 that requires enterprises to collaborate and connect with their customers through social media, such as Facebook and Twitter (Cheng and Ab Hamid, 2011), and also through online review which is a form of electronic word of mouth (e-WOM). Online review encourages or discourages other consumers from buying a tourism product or service. The reviewer effectively makes it to other review (Racherla et al., 2013). All of these concepts are important elements and components of e-CRM. Intrinsically, e-CRM solutions help companies to evaluate customer loyalty, retention and profitably through repeat visit and tourist's expenditure. E-CRM is an analytical tool to explore consumers fluctuates in their wants, preferences, buying behavior and price interaction (Kriemadis, Kotsovos and Kartakoullis, 2009). E-CRM techniques use non-electronic methods and software application. Such techniques as: intelligent agent technologies, the call centre that links to web sites, and the use of data warehousing techniques, help companies manage the analysis of customer needs and desires (Constantelou, 2002). Moreover, CRM software provides companies more organized and efficient information about their customer (Pulevska, 2008). CRM was originated from customer relationship marketing. It is related to customer relationship marketing principles that have existed since the beginning of the tourism business itself as its practical application (Gummesson, 2004).

Finally, the evaluation of e-CRM adoption in tourism business and travel agencies also depends on the type of a company activity. A company has a lot of business that require double effort to handle management and administrate its customer database (Constantelou, 2002). The two main questions that motivated this study are: RQ1: To what extent the e-CRM is important for Egyptian tourism sector? RQ2: How can e-CRM help online travel agencies? Due to the increased use of the internet in the tourism sector, e-CRM is becoming an important channel for customer and travel agencies to communicate and interact. Accordingly, the research aims at 1) defining the concept of e-CRM, and 2) understanding the role of the e-CRM in helping the on line Egyptian travel agencies in obtaining the needed information about their customers. In addition, the research attempts to answer the question: to what extent the e-CRM is important for the Egyptian tourism sector.

\section{Literature Review}

\section{The e-CRM concept}

E-CRM is defined as an approach, method, software, telecom and Internet capabilities that help and support an organization to analyze, manage, and evaluate customer relationships effectively and professionally (Caribbean Tourism Organization, 2013). As e-CRM is the practice of costumer relation management that applies in a company's website, it consists of hardware, software, processes, applications, and management (Sigala, Marianna, Christou, Evangelos, 2006). CRM aims at establishing, maintaining, enhancing and commercializing customer relationships through a better understanding of customer requirements, needs and desires (Peters, 1997). Moreover, the e-CRM provides companies with direct and indirect impact on customer satisfaction, loyalty, sales and profit (Rigby et al., 2002; Feinberg et al., 2002; Romano and Fjermestad, 2003). In addition, CRM is an application for methodologies, processes, systems and software that help organizations and travel agencies to manage customer relationships in an organized and effective manner (Bernett and Kuhn, 2002). Successful e-CRM requires attracting and keeping valuable customers. Furthermore, relationship marketing emphasizes building relationships that lead to customer retention and long-term customer loyalty, besides marketing activities. The main target of the e-CRM is making an immediate purchase (Fjermestad and Romano, 2003).

Therefore, e-CRM is an approach or method that helps travel agencies to compete and gain competitive advantage. CRM provides companies with functions related to customers such as marketing, customer service and sales. These functions support companies to create a business strategy to keep customer satisfaction and loyalty (Pan and Lee, 2003). Consequently, e-CRM is a technical and devised method to facilitate innovation and enable unique business models of the company. It allows potential opportunities for the success of business (Constantelou, 2002). Anderson suggested that $64 \%$ of company's profit is due to performance level of e-CRM in the company (Kumar, 2010).

\section{E-CRM and the Tourism Sector}

The tourism industry has begun with Computer Reservation System in the 1970s followed by Global Distribution System, through the adoption and development of ICTs. ICTs have linked between customers and providers with direct interaction (European Commission, 2003). Thus, tourism enterprises can apply e-CRM on their websites to sustain customer satisfaction and to assist in building a long term and effective customer relationships while maximizing profitability (Kuttainen, Christe, Iliachenko, Elena, Salehi-Sangari, Esmail, 2005). More to the point, concepts such as online review and social media are important elements and components of e-CRM. Online review is a type of word of mouth (WOM), 
The Role of Electronic Customer Relationship Management in Tourism Sector:

which can be measured by two methods. The first is the number of reviews written by customers. The second is the amount of information which they provide via the reviews to other consumers (Racherla et al., 2013). E-WOM has been used as an indicator of service providers' perceived quality in order to evaluate the impact of online reviews on tourism product sales (Chevalier \& Mayzlin, 2006). Social media, such as Facebook and Twitter have become the most commonly, successfully, and effectively used in travel and tourism as well as, web 2.0 or travel 2.0(Milano et al., 2011). Furthermore, social media is the online platform that customers use to share opinions and experiences with each other and with organizations, and help them to control and use different media easily, and consequently, at a lower cost. It enables communication and collaboration on a massive scale (Turban et al., 2008). Therefore, social media, WOM, and online review are key elements or important tools to achieve effective and successful e- CRM. Through these elements customer can share, change, communicate, and collaborate opinions and experiences with each other. For that reason, these elements help customer to make a decision and purchase their products. In addition, travel agencies can evaluate and measure the responses of their customers.

As a result, e-CRM makes use of the Internet and ICTs technologies and applications to connect with customers for successful customer relationship management, and thus manage information about the customers. Competitive advantage in the tourism industry requires more researches about the demand markets, segments and customer needs. The competitive advantage needs more efforts and high quality of products and services. The shift from customer oriented to customer-driven business processes, more experienced tourists, and more mature tourists, has led to new challenges in customer needs and motivations. Tourists are more in-depth and professional, and want personalized products and services for the best rates available (Aspect Communications, 2007). Constantelou's survey on European travel agencies reported that customers have increased in number because of their companies' existence on the Internet. French companies estimated British customers who use the Internet by $15-20 \%$ of all internet customers and thus support sales in North America (Constantelou, 2002). Additionally, e-CRM is the appliance of e-commerce and e-business applications in tourism. Travel agencies that adopt e-CRM solutions use it as a tool to develop their relationships with current and prospect customer, instead of the traditional view of marketing perspective. E-CRM business strategies consist of marketing, sales, operations, finance and human resource management, as well as information technologies, to maximize profitability of customer interactions (Stiakakis and Christos, 2009). TravelNow.com is a website for a travel agent who evaluates their customers' response to promotion and marketing via newsletters that link with web address (URLs). This email massages contain HTML to help customers see products with a picture and details. As a result, customers can enjoy best prices available by personalizing the massages and newsletters (Alford, 2001).

On the other hand, e-CRM is also defined as the application of ICT to enhance and increase the quality and scope of customer service in tourism (Kotorov, 2002). At the same time, as Singh (2002) also exposed, the structure of customer relationships online depends on e-CRM strategy components. There are more concepts to identified e-CRM strategy. These strategies are called e-CRM functions, such as operational e-CRM products which used to provide front office activities including sales, services and operations; analytical e-CRM products which are used for process data, improving relationships, effective marketing; and finally, collaborative e-CRM products which are used for communicating with the customers online, personalizing services (Dyche, 2001 and Karimi et al., 2001). Such systems use ICTs applications to help and integrate various business functions to achieve consistency, harmonization, coordination, improved information management and customer needs (Tatari et al., 2007). E-CRM is a combination of hardware, software, process, applications and management to enhance customer service, retain customer, and provide operational, collaborative and analytical capabilities (Romano and Fjermested, 2002). To gain the advantages of IT applications, the organization needs construction to recognize and assess the financial benefits and revenue from business (Love and Irani, 2004). Tourism companies should analyze the demand and segments for marketing purposes. Kotler (1994) defines marketing as 'the task of successfully hiring, training and motivating able employees to serve the customer well'. Companies should attract, motivate, and support employees to achieve the needs and wants of these customers, hence, achieving the targets of the travel agent (Berry and Parasuraman, 1991). Considering that, a firm creates and develops a value-chain relationship, such what leads to an increase in valuable customer and to an increase in company's image and company's value (Mithas et al., 2005). The valuable customers explain or explore the value of the tourism product and service or value chain that matches their needs and wants. In fact, e-CRM is an important factor for all companies. Companies spend more time and money to add a prospect customer for purchasing a new product than to keep current one (Payne, 2002).

ExploringMacedonia.com is Macedonian official tourism portal, a site that incorporates travel information on Macedonia. They explore the use of e-CRM implementation and database in order to store all the information regarding the customers and services suppliers, so that customers can purchase their suitable products. E-CRM technologies will lead to a professional portal, and this in turn leads to customer loyalty and satisfaction. Besides, the implementation of ECRM on Macedonian portal achieves some goals such as improving managerial capabilities and planning processes for the site (Pulevska, 2008). E-CRM systems aim to enhance and develop tourism product and service and keep customer satisfaction and loyalty by strengthening the analytical capabilities. In addition, it is the base to differentiate product and service for valuable customers and the best way to achieve customer's loyalty and retention (Dyche, 2001).

Accordingly, the employers support and retain talented workers by providing opportunities for outstanding employee. Therefore, competition with technological progress will led to successful changes in employment strategy (Osborn-Jones, 2001). Furthermore, Constantelou suggests that valuable CRM relies on the integration between back 
office and front offices processes of a company through customer database. This is an essential tactic to help and support companies to explore demand segments which have the potential to generate and maximize profits (Constantelou, 2002). The evidence for that is the Internet European Travel Monitor study which indicates that in 1999 there were 5.738 million international and domestic trips which were booked and paid online. Utravel.com, a UK online agent, spent around 10 UK pound as customer gaining costs Compared to 14 pound UK for industry and the average rate of industry was $25 \%$. However, uTravel.com average rate was about $60 \%$. Thus, this increase explains customer loyalty and retention that explore the implementation of E-CRM (Alford, 2001). Nevertheless, The STAR research results reveal that the European travel agencies begin to use or test e-CRM application to gain its opportunities. So some agencies are pioneers in adopting e-CRM, while others believe they should move to follow as they don't want to be losers in tourism competition. However, some companies (account for over 90\%) still prefer traditional methods of sale. Moreover, the vast majority of ecustomers prefer personalized services and human interaction that a company provides them directly (Constantelou, 2002). Noticeably, e-CRM plays an important role in tourism industry through the travel agencies, such as single data base for the costumer, using a safe internet connection, coordinating procedures, providing sales, marketing and controlling departments with accurate statistics and reports on customer's and booking data, data visibility, and maintain customer history using automated processes, and exchange data with other systems and partners in tourism sector. Moreover, successful e-CRM needs qualified employees to keep valuable customers with their loyalty to a travel agency.

\section{Customer needs online}

Consumer behavior should be identified in online or offline because every consumer has specific needs. So Cho's study suggests that consumers' WOM behavior should take into consideration many factors, such as customer price sensitivity, customer wants (involvement), and situational influences which result from interaction (Cho, Im, Hiltz, \& Fjermestad, 2002). Furthermore, a study conducted by Dreamticket.com, an online travel agent, explains that online consumers expect favorable prices; a tourism product complies with their needs, a call centre, personalizing priorities or involvements, the availability to save their history search results for booking, and finally high products to meet their needs (Alford, 2001). As well, some European companies define a new customer segment called" web savvy" as realization of needs and an attempt to gain best prices through the use of Internet with e-CRM (Constantelou, 2002).

This is what leads the organization to better data analysis of customer markets and better marketing and advertising efforts. Additionally, CRM tools use in organizing customer data and handling this information to a better customer database which support a company to turn first visit tourists into repeat visit and achieve customers' loyalty and retention (Winer, 2001). Moreover, the repeat visit rely on valuable customer, best price, accessibility, attractions, personalization \& customization, and loyalty programs (Gurnet, Caribbean Tourism Organization). CRM also enhances the ability for tour operators to work together through shared information. The US online travel site connects its online with its offline. On the same level, a company innovates physical presence with independent franchises across the country which link with a CRM software system. Therefore, when customer asks information on the company's website, the question will be returned to the nearest franchise available. So online travel site with e-CRM solution functions as supplement and complementary to traditional travel agents (Constantelou, 2002).

Another successful practice is Thomascook.com, which establishes a system to customers' acquisition through online registration and sales. Customers can register for e-mail updates leaving some information including their preferences trip, contact details, and mobile phone if they want to receive a text message. Through customers' database information, Thomascook.com aims to improve services, by call centre staff. As a result, e-CRM provides advantages or benefits for travel agents, tour operators, tourism organizations and customers through accurate information systems and data base to help them to reduce their costs and maximize profitability. On the other hand, customers would achieve their needs and, thus, attain satisfaction.

\section{The perceived barriers to the adoption of e-CRM solutions in tourism}

According to Constantelou, the main barriers to the adoption of e-CRM solutions are the extent of the tourism market maturity, the financial resources required, the lack of skills and lack of experience in dealing with technology sellers and suppliers, and systems and structure practices within organizations. Considering that, tourism industry that depends on low profits will avoid the high cost of financial investments in the introduction of e-CRM solutions. For some companies the investments in e-CRM should be warranted with the shareholders who share the profit (Constantelou, 2002).

Taking into account the complexity of tourism product and service, consumer desires, behavior and taste change, they are considered as additional barriers to the implementation of e-CRM. In fact, some destinations become fashionable for a certain period while customer's tastes and demands become innovative over time. Consequently, it is difficult to manage the innovation of tourism products (Pulevska, 2008). An absence of strong sponsorship, lack of culture tendency, inadequate supporting budget, inadequate customer management skills (knox, 2001), poor commutations, lack of standardizations in the organization are other barriers (Ozgener and Iraz, 2005). Gurnet suggests that there are more barriers, such as bad advice, lack of CRM understanding, software problems, budget problems, , poor planning, company politics, organizational change (Gurnet, Caribbean Tourism Organization) and security problems regarding online payments (Constantelou, 2002). 
The Role of Electronic Customer Relationship Management in Tourism Sector:

However, according to KPMG's survey, CRM has three key factors for adoption within the travel sector, such as apply e-CRM and benefit from its innovation, customer relationship management which is the travel agency's key differentiators to achieve competitive advantage, and maintaining customer loyalty and retention by identifying priorities. Additionally, Constantelou suggests that there are three integrated factors for e-CRM adoption. First, connect with customers through interactive link with value added tourism products. Secondly, provide customers better service with the availability to purchase products online. Hence, travel agency gains opportunities for profitable and added revenues. Thirdly, e-CRM system reduces information analysis for travel agency (Constantelou, 2002). In addition, Michael Porter illustrated the competitive advantage strategies in three stages, which are cost leadership, product differentiation and customer focus. E-CRM implementation provides the three steps. A customer data leads to personalized communication across channel, so that; it could be a barrier to any competitor (Alford, 2002). E-CRM plays an important role in tourism industry. However, this approach faces many barriers, which have negative effects on tourism sector, such as inadequate budget, lack of customer skills and qualified employees, poor planning, lack of understanding. These factors represent a challenge to adopt and implement e-CRM in tourism industry. Thus, travel agencies should develop them to take the opportunities and gain benefits from using e-CRM technologies.

\section{Research Methodology}

The study covered a total of 400 travel agencies for the questionnaire those who have at least one component of e-CRM as participants; only 50 questionnaires were not valid, or the travel agency didn't respond, and the others didn't have an Internet site at all. The sample members (travel Agencies) have been chosen randomly. Therefore, the survey approach was implemented to collect data from 350 respondents' of the travel agencies using a completed questionnaire technique. To cover the dominant perspectives of travel agencies which participated in the questionnaire, the sample frame was the number of travel agencies in Cairo governorate estimated at 1160 travel agencies in 2012.

The research methodology depended on conducting a well-structured questionnaire which was designed and distributed to a random sample of travel agencies in Cairo Egypt in January /February/March-2013. As a result, a questionnaire was designed to travel agencies which adopted the e-CRM to explain the importance of e-CRM for their functions in tourism and test the understanding of the participant towards e-CRM for tourism. Thus, a series of questions were developed gradually moving from more general statements to more specific ones. There is a kind of a qualitative approach applied for asking tourism companies a number of closed-end questions to decide the reasons behind answering each criterion under different options of the Likert scale from the viewpoints of travel agencies (Walle, 1997).

The questionnaire was simply structured. It contained 18 closed-end questions. It was divided into three parts. The first part focused on the importance of e-CRM in tourism industry. The second part dealt with the utility of e-CRM and how it is useful for tourism. This included the target and the advantages of e-CRM. The final part is designed to evaluate e-CRM status in the travel agency.

On the other hand, the analysis employed descriptive statistics to provide an excess of information. Frequencies, means and standard of deviation, were computed using the Statistical Package of the Social Science (SPSS, Version 16.0). Moreover, statistical models such as statistical means, T-test, analysis and Cronbach's alpha value were used to analyze the data. T-test paired Sample was considered where it was univariate test of significance. It was used to compare between the sample mean and the respondents' answers (Hair, Bush \& Ortinau, 2003). The Likert approach was used to analyze travel agencies attitudes towards implementation of e-CRM in Egypt by answering a number of questions using the options 'Strongly Agree', 'Agree', 'Neutral', 'Disagree' and 'Strongly Disagree'. The other questions were "yes" and "No".

\section{Results and Discussion}

For the purposes of this research, the first part of the questionnaire focused on the concept and the importance of e-CRM in tourism industry.

Table (1): Frequency distribution of viewpoints of respondents

\begin{tabular}{|c|c|c|c|c|c|c|c|c|}
\hline \multirow{3}{*}{$\begin{array}{l}\text { Question N1 If the } \\
\text { company have a web site }\end{array}$} & \multicolumn{4}{|c|}{ Frequencies } & \multirow{2}{*}{ Total } & \multirow{2}{*}{ Mean } & \multirow{2}{*}{$\begin{array}{l}\text { Std.Error } \\
\text { of Mean }\end{array}$} & \multirow{2}{*}{$\begin{array}{l}\text { Std. } \\
\text { Deviation }\end{array}$} \\
\hline & \multicolumn{3}{|c|}{ Yes } & No & & & & \\
\hline & \multicolumn{3}{|c|}{100} & ---- & $100 \%$ & 1.00 & .000 & .000 \\
\hline $\begin{array}{l}\text { Question N2 the } \\
\text { possibility to book online }\end{array}$ & \multicolumn{2}{|r|}{72} & & 28 & $100 \%$ & 1.28 & 0.024 & 0.450 \\
\hline \multirow{2}{*}{$\begin{array}{l}\text { Question N3 Update } \\
\text { information for the } \\
\text { company's site on the } \\
\text { Web }\end{array}$} & daily & weekly & monthly & annually & & & & \\
\hline & 35.1 & 4.9 & 38.6 & 21.4 & $100 \%$ & 2.46 & 0.063 & 1.176 \\
\hline
\end{tabular}


Marwa Fawzi Abdel Warith

Table (2) Frequency distribution of viewpoints of respondents

\begin{tabular}{|c|c|c|c|c|c|c|c|c|c|}
\hline & & & Freque & cies & & & & Std.Err & Std. \\
\hline & s. agree & agree & neutral & disagree & s. disagree & & & Mean & \\
\hline $\begin{array}{l}\text { Question N4 site } \\
\text { contains more than } \\
\text { one language to } \\
\text { reach all segments }\end{array}$ & 44 & 56 & --- & ---- & --- & $100 \%$ & 4.44 & 0.027 & 0.497 \\
\hline $\begin{array}{l}\text { Question N5 Travel } \\
\text { agent should Have } \\
\text { E-CRM }\end{array}$ & 56 & 29.4 & 14.6 & --- & --- & $100 \%$ & 4.41 & 0.039 & 0.732 \\
\hline \begin{tabular}{lr}
\multicolumn{2}{l}{ Question N6 } \\
company \\
interested \\
develop is \\
relationship \\
$\begin{array}{l}\text { customer } \\
\text { the site }\end{array}$
\end{tabular} & 25.1 & 74.9 & --- & --- & --- & $100 \%$ & 4.25 & 0.023 & 0.434 \\
\hline $\begin{array}{l}\text { Question N7 The } \\
\text { main objective of } \\
\text { the site to increase } \\
\text { customer }\end{array}$ & 48.9 & 51.1 & --- & --- & --- & $100 \%$ & 4.49 & 0.027 & 0.501 \\
\hline $\begin{array}{l}\text { Question N8 Use } \\
\text { the site for } \\
\text { marketing and } \\
\text { distributing tourism } \\
\text { product. }\end{array}$ & 58.9 & 41.1 & --- & --- & --- & $100 \%$ & 4.59 & 0.026 & 0.493 \\
\hline $\begin{array}{l}\text { Question N10 Site } \\
\text { is use to find } \\
\text { suppliers }\end{array}$ & 24.3 & 2 & 72.9 & --- & 0.9 & $100 \%$ & 4.20 & 0.029 & 0.550 \\
\hline $\begin{array}{l}\text { Question N11 } \\
\text { stories and } \\
\text { experiences that } \\
\text { tourists write and } \\
\text { tell about their trips } \\
\text { in destinations } \\
\text { affect the decision } \\
\text { of other tourists }\end{array}$ & 38.6 & 49.4 & 2 & 9.1 & 0.9 & $100 \%$ & 4.16 & 0.049 & 0.909 \\
\hline $\begin{array}{l}\text { Question N12 The } \\
\text { usefulness of e- } \\
\text { CRM's feedback }\end{array}$ & 16.9 & 70.6 & 12.6 & --- & --- & $100 \%$ & 4.04 & 0.029 & 0.542 \\
\hline $\begin{array}{l}\text { Question N13-mail } \\
\text { help agency to } \\
\text { realize customer } \\
\text { needs and wants to } \\
\text { achieve. }\end{array}$ & 52.6 & 47.4 & --- & --- & ---- & $100 \%$ & 4.53 & 0.027 & 0.500 \\
\hline $\begin{array}{l}\text { Question N14 E- } \\
\text { CRM considered as } \\
\text { a link to } \\
\text { communicate with } \\
\text { customers and } \\
\text { deliver their wishes }\end{array}$ & 40 & 60 & --- & ---- & --- & $100 \%$ & 4.40 & 0.026 & 0.491 \\
\hline $\begin{array}{l}\text { Question N15 } \\
\text { reduced cost of } \\
\text { Tourism Marketing } \\
\text { for the company } \\
\text { through the } \\
\text { website. }\end{array}$ & 32.3 & 47.4 & 19.4 & 0.9 & --- & $\begin{array}{c}100 \\
\%\end{array}$ & 4.11 & 0.039 & 0.735 \\
\hline
\end{tabular}


The Role of Electronic Customer Relationship Management in Tourism Sector:

\begin{tabular}{|c|c|c|c|c|c|c|c|c|c|}
\hline $\begin{array}{l}\text { Question N16 E- } \\
\text { CRM helps } \\
\text { agencies to enhance } \\
\text { the destination's } \\
\text { competitive } \\
\text { advantage. }\end{array}$ & 16.9 & 83.1 & --- & --- & --- & $100 \%$ & 4.17 & 0.020 & 0.375 \\
\hline $\begin{array}{l}\text { Question N17) E- } \\
\text { CRM helps to keep } \\
\text { tourists' loyalty. }\end{array}$ & 48.3 & 51.7 & --- & --- & --- & $100 \%$ & 4.48 & 0.027 & 0.500 \\
\hline $\begin{array}{c}\text { Question N18 } \\
\text { Barriers faces travel } \\
\text { agency to adopt e- } \\
\text { CRM }\end{array}$ & 42.9 & 46.6 & 10.6 & --- & --- & $100 \%$ & 4.32 & 0.035 & 0.657 \\
\hline
\end{tabular}

The result of table (1) explains that all of the travel agencies have a website to illustrate the tourism products of the company, which emphasized the increasing use of the internet. Question (2) indicates that around $72 \%$ of the samples have online reservation directly from the site, while, $28 \%$ of the sample do not have. Then the $28 \%$ that do not have online reservation, their customer should go to the agency to make a reservation, spending a long time and a lot of money. Therefore, e-CRM reduces time and money for customer with online reservation, and that is what a customer needs online. This confirms that the vast majority of travel agencies have website and online reservation. Moreover, European travel agencies reported that customers have increased in number because an agency has a site on the internet. British customers use internet to book in French companies as a percentage of $15-20 \%$ of all customers and thus support sales of the group in North America. However, Egyptian travel agencies need more effort to enhance their sites.

For updated information, the results explain that about $38.6 \%$ of the samples update their information monthly, $35.1 \%$ daily $21.4 \%$ annually, and $4.9 \%$ weekly. However, companies' sites should update and innovate their information daily to keep in touch with the new trends of customers and to remain valuable customers' loyalty to a specific travel agency. This is consistent with the database of Thomascook.com that used customers profile by call centre staff to improve and develop their services. Therefore, $35.1 \%$ of the samples update their information daily to achieve customer's satisfaction and loyalty. As a result, Egyptian travel agencies make use of the Internet and ICTs technologies and applications to connect with customers for successful customer relationship management, and thus manage information about the customers. Nevertheless, they should give more attention to develop their sites.

Regarding languages of the site (table 2), around 56\% and 44\% agreed and strongly agreed that a travel agency's site should contain more than one language to reach all markets and segments and to collect data about customers' needs, wants, desires, and motivations to maximize profitability of customer interactions. Furthermore, a customer should achieve his needs and wants to be satisfied. This is called collaborative CRM products that are used for communicating with the customers' online and personalizing services. Egyptian travel agencies that adopt e-CRM solutions use it as a tool to develop their relationships with current and prospect customer, through different languages. Around 56\% of the sample indicated that they strongly agree that they should have electronic customer relationship with their tourists such as e-mail, chat room, and call center. The other $29.4 \%$ agreed and $14.6 \%$ were neutral. That is also what customer needs on line, and this explains that online consumers are looking for clear definite pricing, a call centre, product offering matching their needs, customer privacy, which will be a top business priority of customer relationship management. This is called operational CRM products that are used to provide front office activities, including sales, service and support. Furthermore, in Europe the travel agencies begin to use or test E-CRM application to fulfill its opportunities. So some agencies are pioneers in adopting e-CRM, while others should move to follow. However, some companies (over 90\%) still prefer traditional methods of sale. Thus, the vast majority of the sample support e-CRM solutions, but others stand as spectators. Therefore, the vast majority of the Egyptian travel agencies still prefer traditional methods of sale, may be because they have problems and barriers to adopt all the components of e-CRM. In addition, the results explain that, travel agencies develop their relationship with their customers through sites with $74.9 \%$ and $25.1 \%$ of the sample agreed and strongly agreed. This highlights the important role of electronic customer relation management for tourism, in providing a high quality product to their customers. This is called analytical CRM products, which are used for processing data, improving relationships, marketing efficiency in different ways. Like the Macedonian portal which has improved its efficiency and effectiveness by the use of e-CRM application, so a company can acquire customers via its professional site. Egyptian travel agencies build and create a strong relationship with their customers through a value-chain relationship, such what leads to an increase in valuable customer and to an increase in company's image and company's value and finally a unique destination image.

The second part of the questionnaire focused on benefits and targets of e-CRM in tourism industry. Regarding target of the site, results show that $51.1 \%$ and $48.9 \%$ of the sample agreed and strongly agreed that increasing customers' numbers were the main target of the site. Therefore, travel agencies make sure that customers always are their main target as they are the first in their interests and priorities. By the use of the internet with e-CRM application, travel agencies explore new customer segments that are called "web savvy". These customers know their needs and try to get it at the 
best price. This is the target of e-CRM to acquire new customers and retain them. Furthermore, some of the Egyptian travel agencies use Social media, such as Facebook, Twitter and web 2.0 or travel 2.0 to help customer to make a decision and purchase their products.

Results indicate that the greatest percentage of the sample agreed $41.1 \%$ and strongly agreed $58.9 \%$ that their site is used for tourism marketing and services, with a positive mean value .So that Egyptian travel agencies used analytical e-CRM for process data, improving relationships, effective marketing. Hence, e-CRM has been regarded as one of the most important concept in managing and tourism marketing, as the primary goal of making a one-time and immediate sale to the customer. This confirms the suggestion of Anderson who decided that $64 \%$ of companies' profit is due to performance level of e-CRM in the company. Therefore, e-CRM is considered as a tool for marketing and managing tourism business. For the use of site to find or increase suppliers, the sample's point view is divided into: strongly agreed $(24.3 \%)$, agreed $(72.2 \%)$, neutral $(2 \%)$, and strongly disagreed $(0.9 \%)$. The vast majority of them confirm the use of their site to find the providers and as a distribution channel to their tourism products. Besides, e-CRM also enhances and improves the ability for tourism operators to work together through shared information. Moreover, European airline companies need to strengthen relationship with travel agencies as a supplier because they represent $70 \%$ of revenue sources, and e- business adoption might increase direct sale and profit to any airline. In the same way, $72.2 \%$ of the travel agencies also try to find suppliers or intermediaries to increase sale and maximize profit.

Regarding tourists' stories and experiences, the results indicated that the entire sample is divided into five choices; s. agreed $(38.6 \%)$, agreed $(49.4 \%)$, neutral $(2 \%)$, disagreed $(9.1 \%)$, and s. disagreed $(0.9 \%)$. Therefore, the greatest percentages indicate positive value that tourists can write and tell stories and experiences about their visit through the implication of web 2.0 such as Facebook, Twitter and e-WOM. These elements support e-CRM to encourage or discourage other customers from buying tourism product. Throughout telling stories and experiences, travel agencies could use analytical e-CRM for processing information, improving relationships, and marketing effectiveness. As a result, Egyptian travel agencies divide into three categories, companies have Facebook, Twitter, and e-WOM, Companies have one or two component of these elements, and finally companies do not have.

The third part of the questionnaire concentrated on the evaluation of e-CRM in the tourism industry. From table (2), around $70.6 \%$ agreed and $16.9 \% \mathrm{~s}$. agreed that the feedback from e-CRM is used to develop and enhance the site and the relationship with customers. Obviously, Egyptian travel agencies use e-CRM to the establishing, maintaining, enhancing and commercializing customer relationships through understanding of a customer's needs and desires. In addition, valuable e-CRM relies on the integration between back office and front offices processes of a company through customer database. This is an essential tactic to help and support Egyptian companies to explore demand segments, which have the potential to generate and maximize profits. The best practice is Thomascook.com, which established a system to acquire new customers through online registration including some personal data about their customers to connect them with their new products. Therefore, e-CRM is used to develop and enhance the site and the relationship with customers for the tourism sector. There were around $47.4 \%$, agreed and $52.6 \% \mathrm{~s}$. agreed that e-mail helped them to recognize needs and wants of customers. E-mail is considered the main tool for e- CRM beside the chat room and the call centre. Egyptian travel agencies have some elements of e-CRM such as email, chat rooms, interactive websites, and e-forums. Hence, they try to keep in touch with their customers through e-mail to keep customer satisfaction, loyalty, and retention. Moreover, Travel Now.com emailed newsletters to their customers with URL to evaluate responses. These email massages contain HTML to help customers to see products with a picture and details. As a result, customers can enjoy best prices available by personalizing the massages and newsletters. This is the most prominent positive role for e-mail for marketing and promotion.

Regarding e-CRM as a tool to communicate with customers and receive their wishes, results show that the majority of responses were positive $60 \%$, agreed and $40 \% \mathrm{~s}$. agreed, describing the e-CRM as a communication channel with customers to realize the desires and motivations of tourists. As tourists are professional consumers, they want personalized products and services for the best rates available. Furthermore, Egyptian travel agencies can depend on their websites to determine customer needs online to develop customer satisfaction and assist in building beneficial and successful customer relationships through the use of (e-CRM). Although, they small or medium enterprises, they could success. Dreamticket.com, the online travel agent which suggested in its study, that customers need best price, integrated call centre, product offering, personalized services, and good customer relationship management. For reduced cost of tourism marketing for the company through the website, the results indicate a positive trend through the website of travel agencies, which reduced their marketing cost via e-CRM with high percent to agree $47.4 \%$ and $32.3 \%$ s. agree. However, the others didn't believe that or they didn't know. In fact, marketing emphasizes building relationships that lead to customer retention and customer loyalty, besides traditional transactional marketing. As a result, this high percentage explains that the main goal for Egyptian companies is making an immediate sale to the customer depending on e-CRM strategy. The structure of this strategy includes collaborative, analytical, and operational functions. This database helps them to reduce their costs and maximize profitability. It is the base to differentiate product and service for valuable customers and the best way to achieve customer's loyalty and retention. Furthermore, the experience of Utravel.com, the UK online travel agency reduced their customer gaining cost to 10 pounds and increased their profit to $60 \%$ through eCRM solutions in 1999. 
The Role of Electronic Customer Relationship Management in Tourism Sector:

The results show that, there are positive indicators towards the role of e-CRM in supporting and enhancing destination's competitive advantage as $16.9 \%$ s. agree and $83.1 \%$ agree. Moreover, e-CRM is a tactic, which is applied to increase the competitiveness between travel agencies. Egyptian travel agencies emphasis the important role of e-CRM as a business strategy providing complete combination of business functions for contacting the customers to differentiate their products and to achieve destination's competitive advantage. Porter suggested that these functions are cost leaderships, product differentiation and customer focus; therefore, e-CRM is used as a tool to achieve destination's competitive advantage. Around 51\% agreed and 48.4\% s. agreed that e-CRM remain the loyalty of the tourists. In addition, e-CRM has a direct and indirect impact on customer satisfaction, loyalty, sales and profit. Furthermore, the application of successful Customer Relations Management through (e-CRM) provides such an opportunity to gain customer loyalty. Egyptian companies, manage their relationships with intermediaries and customers, to develop customer satisfaction and loyalty. As the Macedonian site improved managerial capabilities and planning process for the site creating customer loyalty and satisfaction. There are around $46.6 \%$ agreed and $42.9 \%$ s. agreed that travel agencies faced problems and barriers. Nevertheless, $10.6 \%$ did not know. These barriers are lack of financial resources, lack of skills, and lack of experience in dealing with technology with sellers and suppliers, lake of modern devices and poor planning. Certainly, the complexity of travel products and regular ongoing changes in consumer tastes and behaviors are considered as additional barriers facing the adoption of e-business methods in CRM and stand as a challenge for the industry. Egyptian travel companies face many barriers to apply a successful model of e-CRM. These obstacles are represented in lack of financial recourses, lack of experiences and skills, poor planning, and inadequate customer management skills. Another barrier is the preference of $90 \%$ of the European travel agencies to the use of traditional methods of sale. Besides, the vast majority of customers still prefer human interaction and personalized services from their company.

Table (3) Frequency distribution of viewpoints of travel agencies

\begin{tabular}{|c|c|c|c|c|c|c|c|}
\hline $\begin{array}{c}\text { Question N9 targeted } \\
\text { segment }\end{array}$ & \multicolumn{3}{|c|}{ Frequencies } & Total & Mean & $\begin{array}{c}\text { Std.Error } \\
\text { of Mean }\end{array}$ & $\begin{array}{c}\text { Std. } \\
\text { Deviation }\end{array}$ \\
\cline { 2 - 9 } & customer & company & $\begin{array}{c}\text { Customer } \\
\text { \&company }\end{array}$ & & & & \\
\cline { 2 - 8 } & 37.4 & 11.1 & 51.4 & $100 \%$ & 2.14 & 0.050 & 0.934 \\
\hline
\end{tabular}

The results of table (3) show that $37.4 \%$ of travel agencies decided that customers were the targeted segment. The other $11.1 \%$ decided that companies were their targeted segment. Meanwhile 51\% were sure that customer and company are their targeted segment. As a result, the aim of electronic customer relationship management (e-CRM) systems in tourism is to improve customer service, maintain valuable customers, and to help in providing analytical statistics about customers. Therefore, e-CRM is an applied approach, which increases the competitiveness between travel agencies to reach high quality products. Moreover, a firm can develop a value creation relationship, such as that an increase in customer value leads to an increase in travel agency value and image. As a result, Egyptian travel agencies increase their targeted segment to enhance their market share and distribute their products. Moreover, e-CRM enhances the ability for tour operators and travel companies to work together through shared information. The successful experience in this field is the US online travel site that connected its online with its offline. On the same level, the company has innovated its presence with independent franchises all over the country. Therefore, when a customer asks information on the company's website, his/ her question will be sent to the nearest franchise available. So online travel site functions as supplement to traditional travel agents.

To sum up, all of the questions had low value Std. Error of Mean and Std. Deviation while the mean values were positive except the possibility to book online and update information for the company's site on the Web. In addition, the majority of the responses referred to the positive trends which highlighted the importance and benefits from e-CRM adoption for the Egyptian tourism sector. Nevertheless, there were some misunderstanding, some barriers and obstacles, which face Egyptian travel agencies to adopt e-CRM. As a result, these barriers prevented or hindered travel agencies to adopt a successful e-CRM. 
Marwa Fawzi Abdel Warith

Table (4) e-CRM Paired Samples T-Test

\begin{tabular}{|c|c|c|c|c|c|c|c|c|c|}
\hline & & \multicolumn{5}{|c|}{ Paired Differences } & \multirow[b]{3}{*}{$\mathrm{t}$} & \multirow[b]{3}{*}{$\mathrm{df}$} & \multirow{3}{*}{$\begin{array}{l}\text { Sig. (2- } \\
\text { tailed) }\end{array}$} \\
\hline & & \multirow[b]{2}{*}{ Mean } & \multirow{2}{*}{$\begin{array}{c}\text { Std. } \\
\text { Deviatio } \\
\mathrm{n}\end{array}$} & \multirow{2}{*}{$\begin{array}{l}\text { Std. Error } \\
\text { Mean }\end{array}$} & \multicolumn{2}{|c|}{$\begin{array}{l}95 \% \text { Confidence } \\
\text { Interval of the } \\
\text { Difference }\end{array}$} & & & \\
\hline & & & & & Lower & Upper & & & \\
\hline $\begin{array}{l}\text { Pair } \\
2\end{array}$ & $\begin{array}{l}\text { Q11 - } \\
\text { Q12 }\end{array}$ & .114 & .929 & .050 & 017 & .212 & 2.301 & 349 & .022 \\
\hline $\begin{array}{l}\text { Pair } \\
3\end{array}$ & $\begin{array}{l}\text { Q5 - } \\
\text { Q13 }\end{array}$ & - & .847 & .045 & $-.201-$ & $-.022-$ & $-2.460-$ & 349 & .014 \\
\hline $\begin{array}{l}\text { Pair } \\
7\end{array}$ & $\begin{array}{l}\text { Q13 - } \\
\text { Q14 }\end{array}$ & .126 & .691 & .037 & .053 & .198 & 3.405 & 349 & .001 \\
\hline
\end{tabular}

Table (5) Reliability of e-CRM

\begin{tabular}{|c|c|}
\hline $\begin{array}{c}\text { Cronbach's } \\
\text { Alpha }\end{array}$ & N of Items \\
\hline 0.721 & 4 \\
\hline
\end{tabular}

In order to examine $\mathrm{T}$-Test, paired sample in Table (4) between:-

- Questions (17) \& (18): E-CRM helps to keep tourists' loyalty, Barriers faces travel agency to adopt e-CRM. The value of $t$ is (3.572) and its (2-tailed) significance is (0.01). The result is consistent with the null hypothesis $(0.01$ was below 0.05). Therefore, the difference between the two levels is significant.

- Questions (5) \& (17) Travel agent should have e-CRM, and e-CRM helps to keep tourists' loyalty. The value of t 2.222and its (2-tailed) significance is (0.027). The result is consistent with the null hypothesis $(0$. .027 was below 0.05). Thus, the difference between the two levels is significant. As a result, e- CRM helps an agency to realize customer needs and wants to achieve loyalty. Therefore, the chosen criteria are significant for e-CRM in this case.

- Questions (13) \& (14): e-mail helps agency to realize customer needs and wants to achieve them, and e-CRM is considered as a link to communicate with customers and deliver their wishes. The value of t (3.405) and its (2tailed) significance is (.001). The result is consistent with the null hypothesis $(0.001$ is below 0.05$)$. Thus, the difference between the two levels is significant.

From the previous results and test, there is a significant relationship between e-CRM and the success of the tourism sector in Egypt, and this is the main objective of this study. From these tests, Egyptian SMTEs could prove that they at least realized the important role of e-CRM for their business to communicate with customers to achieve their wants. Therefore, they applied some component of e-CRM. However, there are some companies that still believe in the traditional way to win the competition. However, about $80 \%$ of the travel agencies, which represented in the sample, were small and medium tourism enterprises, but they should take the advantages of information technology to be stronger. Although they had many barriers to adopt this technology (e-CRM), if they begin with a site on the Internet and some of its implications it would support their business and their image. So, many of these travel agencies have some components of e-CRM which could support them in the future to take the full advantages of e-CRM. From the above results of T-test, there is a significant result that the application of e-CRM in SMTE and the use of e-mail to know customer needs and wants prove the aims and objectives of the research. Based on the statistical mean value of the chosen criteria and the results of qualitative analysis, the main indicators behind the respondents' positive behavior relating to the importance of e-CRM criteria for tourism can be summarized in Table 2. The statistical mean of measures ranged from 2.14 as the least limit to 4.59 as the greatest limit. This means that the travel agencies' responses were positive because the range of statistical means in average (4.04) matched the option of 'Agree' using the Likert scale; thus, e-CRM is very important and very beneficial for the tourism sector. In addition, the difference between the upper and the lower responses is 
The Role of Electronic Customer Relationship Management in Tourism Sector:

significant because the value of the $\mathrm{T}-$ Test paired sample for the chosen criteria is $<0.05$. This reflects a strong relationship between the chosen variables or criteria, and the suggested parameter estimates are significant.

The reliability of the chosen criteria has been achieved because Cronbach's alpha value 0.751 is greater than 0.70 . (Note that a reliability coefficient of 0.70 or higher is considered "acceptable" in most social science research situations.) As the table shows, the reliability analysis of alpha coefficient is 0.751 , which is regarded as acceptable reliability coefficients, and suggesting that the items have relatively high internal consistency. Therefore, the results that can be abstracted from the chosen criteria are valid and reliable. (Green et al., 2000; Babakus et al., 2003). The chosen criteria are: the travel agent should have e-CRM, the company is interested in developing their relationship with customer through the site, the usefulness of e-CRM's feedback, E-CRM considered as a link to communicate with customers and deliver their wishes, E-CRM helps agencies to enhance the destination's competitive advantage, Barriers faces travel agency to adopt e-CRM and e-CRM helps to keep tourists' loyalty. Counesanteta's study explores that European airline companies need a good relationship with travel agencies because they represent $70 \%$ of revenue sources. Besides, e-business adoption, which might increase, direct sale and profit to any airline (Constantelou, 2002). On one level, the importance of e-CRM for travel agents and the airline's staff seems to be on the same level of importance for tourists. Since the failure to appreciate the important role of e-CRM will lead to customer dissatisfaction. E-CRM will require efficiency to identify demands and to link up with partners to meet these demands productively and to provide personalized products and services. This study tries to explore the important role of e-CRM for the tourism sector in Egypt.

\section{Conclusion}

Electronic customer relationship management (e-CRM) is progressively more becoming an important approach. However, academic understanding of this approach in the tourism and hospitality field is relatively weak when compared to other fields. The purpose of this study is to examine the degree to which the tourism sector has e-CRM features, with respect to the different types of e-CRM components. In other words, to explain the role of e-CRM in the tourism sector as a new technology to manage the customer relationship with tourists. The main finding of the research is that there is a notable gap in dealing with customer relation management. The travel agent must be customer-centric in order to provide the service with high quality. In fact, e-CRM is a process of evolution, and indication to each next step is often provided by the customer. Therefore, the results confirm that the vast majority of travel agencies in Egypt appreciate the application of e-CRM in their site although there are some companies which didn't have a site and the others have a site but without online reservation. Furthermore, there are barriers and problems that face a travel agency and prevent the successful application and adoption for the Egyptian travel agencies, and appear as a challenge for the tourism sector. Therefore, greater effort should go into improving their perceived reliability and usefulness. It means that travel agencies must pay more attention to improve their relationship with customers to satisfy their needs .Steps should be taken to understand eCRM behavior of consumers, and strong incentives should be developed to attract prospect customers and maintain current customers.

\section{Recommendation}

In essence, changing travel companies to e-business and e- environment cannot provide the company time to see or to wait. However, they should take into consideration that e-CRM is an evolutionary process with the respect to each next step often provided by the customer (Alford, 2001). The US online travel site connected its online ventures with its interface. On the same level, the company has developed its relation with independent franchises across the country which linked with CRM software system. Therefore, when any customer asks information on the company's website, the nearest franchise would help him. So, online travel site functions as supplement to traditional travel agents.

To sum up, companies with higher levels of perceived e-CRM success claimed significantly higher levels of improvements in customer satisfaction, transaction amounts and frequency, brand image, effective database management and customer targeting, efficient business processes, technology utilization, excellence and innovation in services, improved sales, profitability and decreased service support costs. Furthermore, the Egyptian private and public tourism sector should integrate, coordinate and collaborate to help and support the tourism industry to adopt and apply e-CRM and its components. Hence, they should try to investigate challenges and barriers which face the application of this approach. More researches are needed to examine how other supply chain and suppliers, particularly their customers, can influence the benefits that can be gained from e-CRM technology. As well as the problems and challenges facing this topic need to be considered.

\section{References}

Aspect, "Customer Service in the e-CRM market", available at: www.callcentres.com.au/.../Cust \%20Svc\%20In\%20e . (accessed 27January 2013).

Alford, P (2001), "e-CRM in the travel industry", Travel and Tourism Analyst, vol. 1, No. 1, pp. 57-76 available at:

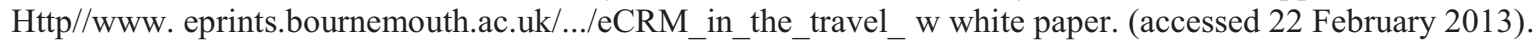

Berry, L.L. and Parasuraman, A. (1991), "Marketing Services. Competing Through Quality". New York: The Free Press. available at: Http// www.amazon.com. (accessed 23 February 2013). 
Beaumont, N.K. (1993), "Social carrying capacity of green island and implications for tourism/recreation planning and management", unpublished B.A. thesis, Department of Geography, James Cook University, Townsville, Australia. available at: http://www.nprsr.qld.gov.au/managing/plans-strategies/pdf/green-island-1999.pdf (accessed 23February 2013).

Buhalis, D.,(1998) "Strategic Use of Information Technologies in the Tourism Industry", Tourism Management, vol. 19, No. 5, pp.409-421.

Buhalis, D., Jun, S. (2011) "E-Tourism" Contemporary Tourism Reviews, Goodfellow Publishers Limited, Woodeaton, Oxford.

Cheng A., and Hamid R., (2011), "The Usability of Hotel Websites in Managing Tourist Expectations: A Customer Relationship Perspective", available at: Http//www.ipedr.com/vol10/9-E00016.pdf (accessed 27 January 2012).

Chevalier, J., \& Mayzlin, D., (2006), "The effect of word of mouth online: Online book", reviews. Journal of Marketing Research, 43, pp. 345-354.

Cho, Y., Im, I., Hiltz, R., \& Fjermestad, J., (2002), "The effects of post-purchase evaluation factors on online vs. offline customer complaining behavior: implications for customer loyalty". Advances in Consumer Research, Vol. 29, No.1,pp. 318-326.

Constantelou, A.(2002), "Emerging Trends in Customer Relation Management Using ICT: the Travel Industry, socioeconomic trends assessments for the digital revolution", STAR (Socio-Economic Trends Assessment for the Digital Revolution) Issue Report No. 22, available at: Http//www.cerna.ensmp.fr/.../TD/4-Constantelou.pdf. (accessed 24 February 2013).

Dyche, J. (2001). "The CRM handbook: a Business Guide to CRM". Boston, MA: Addison Wiley Feinberg, R., and Kadam, R. (2002). "e-CRM web service attributes as determinants of customer satisfaction with Websites". International Journal of Service Industry Management, Vol. 13: pp. 432 - 451. available at: Http//www. is2.1se.ac.uk/asp/aspecis/20060170.pdf . (accessed 27 January 2013).

Feinberg, R., Kadam, R., Hokama, L. and Kim, I. (2002), “The state of electronic customer relationship management in retailing”, International Journal of Physical Distribution and Logistics Management, Vol. 30 No. 10, pp. 470-81. available at: Http// www.emeraldinsight.com/journals.htm?articleid. (accessed 12January 2013).

Feinberg, R., Kadam, R. (2002), "e-CRM web service attributes as determinants of customer satisfaction with Websites". International Journal of Service Industry Management,13: pp. 432-451. available at: http// 140.127.194.87:8080/ECLab/.../10rd/920326_1.ppt. (accessed 24 January 2013).

Fjermestad, J., and Romano, N. (2003). "Electronic customer relationship management: revisiting the general principles of usability and resistance - an integrative implementation framework", Business Process Management Journal, 9:pp. 572 - 591. available at: http//www. citeseerx.ist.psu.edu/.../download? (accessed 27 January 2013).

Ghavamr A., and Olyaer A., (2006) "The impact of e-CRM on customer retention", master's thesis, social science and business administration programmes. available at: Http//www. epubl.1tu.se/1653-0187/.../LTU-PB-EX-0602SE.pdf.(accessed 27 January 2013).

Green, S.B., Salkind, N.J. and Akey, T. (2000) "Using SPSS for Windows, Analyzing and Understanding Data", PrenticeHall, Inc., available at: http://faculty.ksu.edu.sa/73125/Documents/spss.pdf (accessed 27 January 2013).

Greenberg, P. (2002)," CRM at the speed of light: Capturing and keeping customers in Internet real time", $2^{\text {nd }}$ edition, Sydney: McGraw-Hill, available at:http// vishydlharbour.googlecode.com. (accessed 23 February 2013).

Gummerus, J., Liljander, v., P, M., \& Riel, A. v. (2004). Customer loyalty to content-based Web sites: the case of an online health-care service. Journal of Services Marketing,18(3),175-186. available at:Http//www. cdn.ttgtmedia.com/searchCRM/downloads/Ch9.pdf (accessed 27 January 2013).

Gurnett B., "Caribbean Tourism Organization Why CRM needs you?", http//www.onecaribbean.org/.../CrmbriangurnettAntigua_bgurnett@netlab.co.uk available at:http://www.onecaribbean.org/content/files/CrmbriangurnettAntigua.pdf. (accessed 27January 2013).

Hair, J., Bush, R. \& Ortinau, D. (2003)," Marketing Research: Within a changing

Information environment", $2^{\text {nd }}$ ed., Boston: Mc Graw-Hill. available at:http// www.dssresearch.com/.../MailResponseRates.pdf, (accessed 27 January 2012).

Kriemadis, T., Kotsovos, A., \& Kartakoullis, N. (2009). "A Strategy for managing customer relations on the internet: evidence from the football Sector”, Direct Marketing: An International Journal, Vol. 3 ,No.4 ,pp. 229-243. 
The Role of Electronic Customer Relationship Management in Tourism Sector:

Knox R.,(2001), "cross-functional issues in the implementation of relationship marketing through customer relationship(CRM)", European Management Journal, Vol. 19, No.5, pp.534-42, available at: http//www.dspace.lib.cranfield.ac.uk/.../Cross-functional\%2520. (accessed 22 February 2013).

Kotler, P. (1994), "Marketing Management: Analysis, Planning, Implementation and Control", 8th ed. ,Englewood Cliffs, NJ: Prentice-Hall, Inc. available at: Http// www.getcited.com/cits/PP/1/PUB/103084365. (accessed 27January 2013).

Kotorov, R. (2002), "Ubiquitous organizational design for e-CRM. Business Process" Management Journal, 8,pp. 218 232. available at: http/www.is2.1se.ac.uk/asp/aspecis/20060170.pdf. (accessed 25Januray 2013).

Kuttainen, Christe, Iliachenko, Elena Y, Salehi-Sangari, Esmail,( 2005), "Pre-Adoption Customer Satisfaction with Tourism Websites: conjoint analysis of electronic customer relationship management features", The AM2005 Academy of Marketing Conference, Dublin, Ireland, July 4-7, 2005. available at:Http//www. pure.ltu.se/portal/files/649217/Article.pdf. (accessed 27Junuary 2013).

Kumar. D., (2010) ,"Customer Appreciation of E-CRM based Website Services in Banks", SuGyaan Vo.2, Issue NO.1,

Lee-Kelley, L., Gilbert, D., \& Robin, M. (2003). How E-CRM can enhance customer loyalty. Marketing Intelligence and Planning, Vol. 21, No.4, pp. 239-248. available at:Http//www. emeraldinsight.com/journals.htm?articleid.(accessed 25 January 2013).

Love, P.E.D., Irani, Z. and Fong, S.W. (2005), "Management of Knowledge in Project Environments",ButterworthHeinemann,Oxford. available at:Http//www. www.bcu.ac.uk/_media/docs/DE_Jan13.pdf. (accessed 23January 2013).

Mithas, S., Krishnan, M.S., \& Fornell, C. (2005), "Why do customer relationship management ap-plications affect customer satisfaction?" Journal of Marketing, 69pp., 155-166. available at:Http// www.terpconnect.umd.edu/.../mithascrmcs2005.pdf. (accessed 24January 2013). (accessed 14July 2013).

Milano R.,Bodolfo R., Piatttelli R.,(2011),"The effects of online social media on tourism websites, 18th International conference on information technology and travel \& tourism, Innsbruck, Austria, available at: Http//www.iby.it/.../baio_socialmedia.pdf

Osborn-Jones, T. (2001), "Managing Talent: Exploring the New Psychological Contract", UK: Henley Management College. Aspirations. Accounting Education, Vol. 3, No.4, pp. 283-297. Http// www.cipd.co.uk/NR/.../0/manachang1105.pdf. (accessed 27January 2013).

Pan, S. L. and Jae-Nam Lee. (2003), "Using e-CRM for a Unified View of the Customer", Communications of the ACM, Vol. 46, No. 4, 95-99. available at:Http// www.im.cjcu.edu.tw/ mikewu/.../crm/.../E-CRM.ppt (accessed 27January 2013).

Payne, A. (2002), "Customer Relationship Management". available at:Http//www.crm2day.com, (accessed 22 January 2013).

Peters, L., (1997) "IT enabled marketing: a framework for value creation in customer relationships", Journal of Marketing Practice: Applied Marketing Science, Vol. 3, Iss: 4, pp.213 - 229 . available at:Http// www.emeraldinsight.com/journals.htm?articleid (accessed 2 February 2013).

Pradeep Racherla , Daniel J. Connolly \& Natasa Christodoulidou (2013): What

Determines Consumers' Ratings of Service Providers? An Exploratory Study of Online Traveler Reviews, Journal of Hospitality Marketing \& Management, 22:2, 135-161. available at: http://dx.doi.org/10.1080/19368623.2011.645187 (accessed 14 Jul 2013).

Pulevska L., (2008) , "E-CRM in the tourism sector, Journal of tourism" No. 5, http//www.seap.usv.ro/eaat/RDT/.../index.php?. (accessed 27January 2013).

Rigby, D., Reichheld, F.F. and Schefter, P. (2002), “Avoid the four perils of CRM”, Harvard Business Review, Vol. 41, pp. 293-305. available at:Http//www. sb-admin.1parkplace.com/.../Avoid (accessed 27January 2013).

Romano, N. C. and Fjermestad, J. (2002), "Electronic commerce customer relationship management: An assessment of research", International Journal of Electronic Commerce Vol.6 No.2, pp. 61-113. available at:Http// www.citeseerx.ist.psu.edu/.../download? (accessed 1 February 2013).

Romano, N.C. and Fjermestad, J. (2003), "Electronic commerce customer relationship management: a research agenda", Information Technology and Management, Vol. 4,pp. 233-58. available at:Http// www.srlst.com/ijist/ijistVol2N2/ijist22-21-30.pdf . (accessed 27 January 2013). 
Sigala, Marianna, Christou, Evangelos,( 2006), "Investigating the impact of e-Customer Relationship Management on Hotel's Website service Quality", available at:http//www. is2.lse.ac.uk/asp/aspecis/20060170.pdf. (accessed 22 January 2013).

Singh, M. (2002), "e-services and their role in B2C. Managing Service Quality", Vol. 12, pp. 434 - 446. available at:http//www. businessperspectives.org/.../im_en_2006_03_Troster. (accessed 21 February 2013).

Stiakakis E. Christos E., (2009), "Drivers of a tourism e-business strategy: the impact of information and communication technologies", Springer-Verlag. available at:Http.www. users.uom.gr/ stiakakis/download/J[10].pdf. (accessed 21February 2013).

Tatari, O., Castro-Lacoutre, D. and Skibniewski, M.J. (2007), "Current state of construction enterprise information systems: survey research", Construction Innovation, Vol. 7 No. 4 , pp. 310-9. Http//www.home.gwu.edu/ kwak/ERP_Success_Factor.pdf . (accessed 27January 2013).

The European e-Business Market Watch, July( 2003), "ICT \& e-Business in the Tourism Sector", European Commission Enterprise Directorate General. available at:Http//www. ec.europa.eu/enterprise/.../e-business-watch/.../sector. (accessed 27January 2013).

Turban, E., King, D., McKay, J., Marshall, P., Lee, J., and Viehland, D., (2008). "Electronic Commerce 2008: A Managerial Perspective", Upper Saddle River, NJ: Pearson Education, Inc.

Winer, R (2001), "A framework for customer relationship management", California Management review, vol. 43, No. 4, pp. 89 - 106. available at:http//www. jensgulich.wordpress.com/.../a-framework-for-customer. (accessed 27January 2013).

$$
\text { دور إدارة العلاقة مع العملاء إليكترونيا في القطاع السياحي: دراسة حالة لشركات السياحة المصرية }
$$

تعتبر معرفة السائح وخصائصده حاليا من العو امل الهامة لإنجاح السياحة الإليكترونية. وتمثل إدارة العلاقة مع العملاء إليكترونيا إتجاه جديد

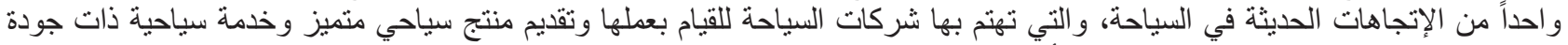

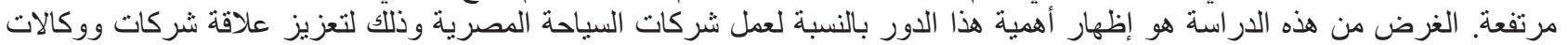

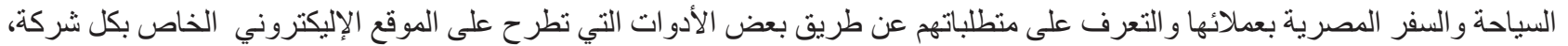

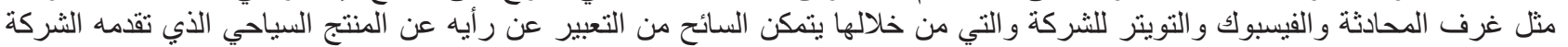

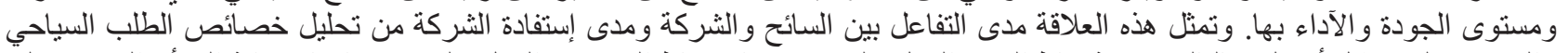

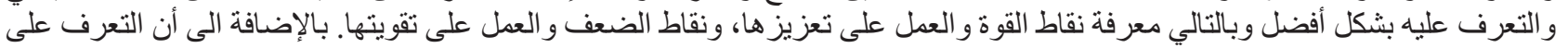

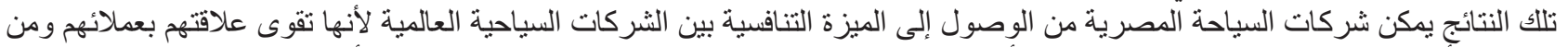

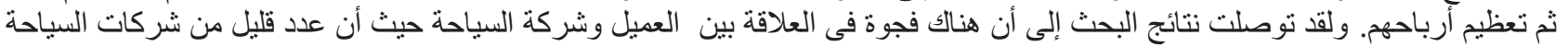

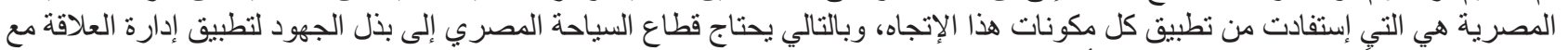
العملاء إليكترونياً بالثكل الصحيح لتحقيق أقصى إستفادة من تطبيقاته. 